of a Public Record Office. The report describes and classifies the historical documents relating to Nigeria, which include Arabic writings dating from the tenth century (though most of these were destroyed during the Fulani conquest of Northern Nigeria) and archives of the British administration dating from 1849 . Of particular interest are the very full minutes kept by the Courts of Equity which settled disputes between European and African traders in the Niger Delta. Other archives are preserved at various local administrative centres; some records have been kept by indigenous administrations, such as Kano and the Egba United Government which, until I9r4, enjoyed a semi-autonomous status. In addition there are the records of public corporations and of missionary societies. All these documents are of great historical interest, and the need for their conservation as national archives has long been recognized. Lack of space and of staff to examine and classify the material, as well as the absence of regulations relating to the destruction of public records, has prevented the systematic administration of these documents. As a result of a survey on which Dr. Dike has been engaged over the past three years, in collaboration with the West African Institute of Social and Economic Research, he recommends the establishment of a record office and the immediate appointment of a full-time archivist to work in conjunction with the survey staff. For the future he envisages the setting up of an Archives Committee representing Government, Churches, prominent Nigerians, the University College and commercial firms; the Committee would ask all departments of Government to initiate a system of examination, arrangement, and numbering of all archives preserved there. The transfer of records from government departments to the record office could then be proceeded with gradually and the relations between a central Record Office and regional offices for the housing of local archives could be worked out.

\title{
Education de base en Oubangui-Chari (A.E.F.)
}

UNE mission d'éducation de base a opéré à Boykota, près de Dékoa, en 1952 sous la direction de M. Pierre Fourré, Directeur du Centre Français d'Information sur l'Éducation de Base. Elle comprenait le personnel africain suivant: un instituteur, une monitrice d'enseignement, un médecin, un infirmier, un moniteur d'agriculture, un ouvrier menuisier, et, de façon intermittente, un instituteur européen et un cinéaste. L'équipe comptait au début deux autres Européens.

Trois buts principaux étaient assignés à l'entreprise: (I) réaliset une expérience d'éducation de base en milieu rural; (2) former et instruire des spécialistes en vue de la continuation de l'éducation de base en Oubangui-Chari et dans d'autres territoires; (3) produire des moyens audio-visuels d'éducation de base pour des missions ultérieures. Les grandes lignes du programme qu'il convenait d'appliquer étaient les suivants : santé et hygiène individuelle; vie familiale et domestique; vie économique; vie sociale; vie civique et morale. L'alphabétisation était l'objectif secondaire de la mission.

L'expérience de Boykota est passée par trois phases: (I) Démarrage: cette période a confirmé que les paysans s'intéressaient aux réalisations qu'on leur proposait mais que le travail collectif bénévole les déconcerte. (2) Phase deux a été marquée par l'extension de certaines activités à deux villages voisins et par l'affermissement de techniques qui ont été lancées en titre expérimental. (3) Au cours de la troisième phase, les activités de la mission se sont étendues à six nouveaux villages. Le meilleur travail a été effectué par le service de santé. Les cours de français parlé ont été fréquentés par une quarantaine d'adultes contre 60 à 75 au début. Par contre l'école a connu un engouement exempt de défaillance.

Le rapport de $\mathrm{M}$. Fourré est consacré aux obstacles qu'il a trouvés sur son chemin, dont le plus grand paraît être l'attitude des femmes: 'Une société quelconque ne peut évoluer sans qu’évoluent parallèlement les femmes qui la composent ... dans la société noire la 
femme ... semble peu favorable aux changements mêmes ceux dont elle ne pourrait que retiret des avantages ... il faut encore avoir le personnel voulu pour entreprendre la tâche d'atteindre le milieu féminin. ... Il n'existe malheureusement pas en Oubangui de jeune fille noire capable d'un tel travail. . . .' Un travail de quatre mois à Boykota et dans la région permettait d'arriver à quelques conclusions : l'éducation de base répond à un besoin et à un désir des populations africaines; des résultats ne sont atteints que lorsque des liens de confiance et de sympathie ont pu être établis entre les éduqués et les éducateurs; on peut espérer que les indigènes foutniront spontanément l'effort nécessaire à leur propre évolution, mais pas rapidement. Le rythme de vie d'un village africain n'est pas bouleversé par la présence d'une equipe d'éducation de base.

[Abrégé d'un article de Jean Chalvet, Nouvelle Revue Frangais d'outre-mer, juillet-août I954.]

\section{Centre d'études de linguistique bantoue (Brazzaville)}

Le cours de langues africaines fondé par M. Eliet le 26 juin I954 a tenu plusieurs séances pendant lesquelles les questions traitées ont été: la structure du bantou, le concept du temps/espace, le verbe 'être', les langues véhiculaires, les emprunts des langues étrangers et les méthodes de leur intégration en bantou. Une conférence a été prononcée par M. Edmond Nzenza Nlandu, rédacteur du mensuel belge Kongo Dia Ngunga, au sujet de l'unification de la langue kikongo.

\section{Soil Conservation}

A REPORT on land erosion in non-self-governing territories ${ }^{1}$ was prepared by the United Nations secretariat for review by the Committee on Information from non-self-governing territories. The report indicates that these territories are specially susceptible to soil erosion and soil exhaustion, as the result of various factors : climate, excessive stock-keeping, bushburning, faulty drainage, \&c. Since soil conservation is bound up with improved farming and proper land use, comprehensive planning for whole agricultural areas is required, and this may involve sweeping social and economic changes. Successful area plans require co-operative efforts between individual farmers and community action under the guidance of government agencies. The report contains information on measures taken in territories administered by Belgium, France, the United Kingdom, and the United States.

\section{Malaria Control}

As a result of a resolution adopted by the I95 I Malaria conference convened at Kampala by the World Health Organization, the Nigerian Malaria service initiated and planned the Malaria Control Project in Gwandu Emirate, Sokoto Province, Northern Nigeria. A series of preliminary surveys led to the selection of Gwandu Emirate, where the disease carried by mosquitoes, which are extremely numerous in that area, causes severe suffering among infants and children. The project in its initial phase covers 600 square miles and will protect a population of $\mathrm{x} 20,000$. Several spraying squads will move from village to village by special vehicles, spraying houses, stables, cattle-sheds, chicken coops, \&c. twice a year. A team of doctors and other specialists will travel all over the country and, using mobile laboratories, will study the progress of the project by assessing the numbers of mosquitoes still alive, and also the improvement in health of the population.

The cost of the project is being borne as to one half by the Northern Regional Government; grants have been received from the International Children's Fund, while the World Health Organization and the Colonial Insecticide Research Committee are contributing by providing specialists.

\footnotetext{
I Soil Conservation, Doc. A/AC. 35/L. I6o.
} 